Hydrol. Earth Syst. Sci., 17, 2083-2096, 2013

www.hydrol-earth-syst-sci.net/17/2083/2013/

doi:10.5194/hess-17-2083-2013

(c) Author(s) 2013. CC Attribution 3.0 License.

\title{
A critical assessment of simple recharge models: application to the UK Chalk
}

\author{
A. M. Ireson ${ }^{1}$ and A. P. Butler ${ }^{2}$ \\ ${ }^{1}$ Global Institute for Water Security, University of Saskatchewan, Canada \\ ${ }^{2}$ Department of Civil and Environmental Engineering, Imperial College London, UK
}

Correspondence to: A. P. Butler (a.butler@imperial.ac.uk)

Received: 22 September 2012 - Published in Hydrol. Earth Syst. Sci. Discuss.: 25 October 2012

Revised: 26 April 2013 - Accepted: 27 April 2013 - Published: 3 June 2013

\begin{abstract}
Quantification of the timing and magnitude of point-scale groundwater recharge is challenging, but possible at specific sites given sufficient high spatial and temporal resolution field observations, and a suitable physically based model. Such models are generally too computationally intensive and have too many unknown parameters to be practically applicable within distributed, larger-scale hydrological or groundwater models. This motivates the need for simpler recharge models, which are widely used within groundwater models. However, it is important that these models are able to capture adequately the unsaturated zone flow processes. We perform an inter-comparison of recharge simulated by a detailed physically based model and a simple recharge model, with both models applied to a field site in the fractured porous Chalk in the UK. Flow processes are simulated convincingly using a dual permeability, equivalent continuum, vertically heterogeneous, Richards' equation model, applied to a 2-D hillslope transect. A simple conventional recharge model was then calibrated to reproduce the water table response simulated by the physically based model. The performance in reproducing the water table was surprisingly good, given the known discrepancies between the actual processes and the model representation. However, comparisons of recharge fluxes simulated by each model highlighted problems with the process representations in the simple model. Specifically, bypass flow events during the summer were compensating for recharge that should have come from slow, continual drainage of the unsaturated zone. Such a model may still be useful for assessment of groundwater resources on a monthly basis, under non-extreme climatic conditions. However, under extreme wet or dry conditions, or under a changed climate the predictive capacity of such models is likely to be inadequate.
\end{abstract}

\section{Introduction}

Quantifying the timing and magnitude of point-scale groundwater recharge, that is the flux of water across the water table into an unconfined aquifer, remains a significant challenge because there is no direct, non-destructive method for measuring this flux in the field. Indirect methods include using chemical measurements (i.e. tracers) and/or physical measurements (e.g. water content, water table response) (Scanlon et al., 2002). With all of these methods, the estimation of recharge requires a conceptual model (that is, a set of assumptions about how the system functions) formulated as a mathematical model (from which quantitative recharge estimates are calculated). One of the problems with using tracers, especially in dual permeability systems, is that the same chemical profile could be consistent with multiple conceptualisations (a classic example is the reinterpretation of the results of Smith et al., 1970, by Foster, 1975, discussed in Mathias et al., 2005). Methods based on physical measurements include: soil water balances (Rushton, 2005; Ragab et al., 1997; Finch, 1998); solutions to some form of 1-D Richards' equation involving soil moisture and/or matric potential observations (van den Daele et al., 2007; Brouyère, 2006; Habets et al., 2010; Ireson et al., 2009b; Ireson and Butler, 2011); and water table fluctuations (Cuthbert, 2010; Ireson et al., 2012). All of these methods have limitations, which may or may not be prohibitive for a given field site. Soil moisture calculations do not rigorously account for the delay and attenuation of the soil drainage by the unsaturated zone, which can be substantial in aquifers with large unsaturated zones (Rushton, 2005). 1-D Richards' equation approaches cannot rigorously represent unsaturated-saturated zone interactions (Ireson et al., 2009b; Ireson and Butler, 
2011), which may be important when water table fluctuations cause significant changes in the unsaturated thickness. As well as the specific yield, water table fluctuation methods require estimates of the net groundwater drainage, typically made using a simplified conceptualisation of the saturated zone (e.g. Fig. 1 in Cuthbert, 2010). Therefore, when addressing the problem of quantifying recharge for any given location, careful consideration of the flow processes in the unsaturated and saturated zones needs to be taken. The most appropriate method will depend on this conceptual understanding of the system (Scanlon et al., 2002).

There is a long history of research into the physical processes that control recharge to the unconfined Chalk aquifers of northwestern Europe, particularly in the UK (see reviews in Mathias et al., 2006; Ireson et al., 2009b; van den Daele et al., 2007 and Butler et al., 2012), France (Habets et al., 2010) and Belgium (Brouyère et al., 2004; Brouyère, 2006). The work in these citations and others (Ireson and Butler, 2011; Ireson et al., 2012) has focused on developing physically based models, and using these models to reproduce field observations. However, these have not yet been implemented into operational distributed groundwater models because they are too complex, requiring a detailed and expensive numerical solution to a system of non-linear, partial differential equations. This results in a large number of parameters and a time consuming solution. Keating et al. (2010) propose a method for calibration and uncertainty assessment of such models using a surrogate model to minimise computational expense. This is a promising approach, but developing a realistic surrogate model for some problems is by no means straightforward. Another approach to this problem is to develop a lumped-scale, physically based model, described by Lee et al. (2007), and references therein, as a representative elementary watershed approach. This is similar to the "integral balance approach" proposed by Duffy (1996), and involves establishing physically based "closure relationships" at large scales (for example the entire unsaturated zone of a watershed). Such an approach is also promising, but establishing effective closure relationships is challenging. Moreover, the resulting lumped model may still be highly complex and require calibration (as was the case in Lee et al., 2007) meaning that the actual benefits of the exercise are questionable.

Other workers have focused on the more pragmatic task of developing a conceptual recharge model for the Chalk, with a less strict focus on the detailed unsaturated zone processes, and more of an emphasis on the larger groundwater system response (Rushton and Ward, 1979; Howard and Lloyd, 1979; Morel, 1980; Jackson and Rushton, 1987; Finch, 1998; Ragab et al., 1997; Finch, 2001; Bradford et al., 2002; Rushton, 2005). Rushton (2005) provides a good summary of conventional approaches for modelling recharge to Chalk aquifers. These typically involve three components. (1) $A$ near surface water balance calculation (such as the Penman, 1950 and Grindley, 1967 approach, see also Chapter 8 of
Allen et al., 1998), which determines soil moisture deficit (SMD), actual evaporation (AE) and soil drainage. (2) A fixed proportion of rainfall and/or rainfall over some threshold (explored in some detail by Rushton and Ward, 1979) which becomes bypass flow that passes directly to the aquifer through the fractures (this dates back to the widely cited study by Smith et al., 1970, and was first applied by Mander, 1977, 1978). (3) Where the unsaturated zone is deep (i.e. $\geq 10 \mathrm{~m}$ ) delayed recharge can occur. Rushton (2005) comments that for "chalk and limestone aquifers the response in observation boreholes is usually within one month of the occurrence of recharge", with exceptions associated with very deep unsaturated zones containing marl bands (see for example Cross et al., 1995). However, findings from previous field studies (Ireson et al., 2009b; Ireson and Butler, 2011) imply that even for a relatively uniform Chalk profile, each of these components is more complicated. More generally, the problem with this approach is that the parameters and process representations within the recharge models may not be well identified by the regional-scale water table surface (Brunner et al., 2012), and errors in the recharge model may be compensated for through calibration of the saturated zone parameters.

In this paper we will try to address these complications by comparing detailed, physically based models, that are consistent with field observations from both saturated and unsaturated zones, with simpler, conventional recharge models, which have not been so rigorously tested against field observations from the unsaturated zone. We apply a two stage approach. The first stage, described in Sect. 2, entails using a physically based model to simulate the water table response in an instrumented 2-D hillslope transect (Sect. 2). This model uses a dual permeability representation of the Chalk and solves Richards' equation for fully coupled saturatedunsaturated flow. From this model, a continuous time series of recharge and groundwater level is extracted from a point in the centre of the hillslope transect so as to minimise the impact of the lateral boundary conditions. We argue that this hybrid data-model approach provides us with the most rigorous estimate of recharge currently available, given that the actual recharge signal cannot be observed. The second stage, described in Sect. 3, involves applying simpler models to attempt to reproduce both the water table response and the recharge signal from the detailed model. This allows us to explore the validity of the process representations within conventional recharge models, and problems of parameter identifiability (Brunner et al., 2012) and equifinality (Ebel and Loague, 2006) within calibrated groundwater models which have no explicit representation of the unsaturated zone.

\section{Physically based hillslope model}

The physically based model used in this study is based on extending the model for 1-D vertical flow in the Chalk 
unsaturated zone presented by Ireson et al. (2009b). The original 1-D model was driven using observations of precipitation and actual evaporation, calibrated against near surface observations of water content and matric potential. As lateral flows are not explicitly represented in 1-D models, a realistic water table boundary condition could not be defined. In this paper, by simulating horizontal flow and including the actively flowing portion of the saturated zone within the model, we are able to simulate explicitly the observable water table response. This provides an opportunity to further test the performance of the recharge model against observations. However, this is not without complications. Firstly, since the resulting numerical model is very computationally demanding, it is not feasible to search the parameter space effectively. Secondly, in a real catchment, saturated zone flow processes are complex: the groundwater divide moves as the groundwater catchment expands and contracts (a particular issue in the Chalk as shown by Parker, 2011); flows converge onto and diverge away from apparent flow lines (Troch et al., 2003); and flow directions change. Three-dimensional models can, in principle, capture these effects, but it is still very difficult to identify static domain boundaries for which states or fluxes can be quantified (a problem that is sometimes addressed in groundwater models by simulating an area that extends beyond the domain of direct interest, see Parker, 2011; Jones et al., 2012). In this study we use a 2-D hillslope transect, which is justified on the basis of observations of the water table elevation in the surrounding area, described in Sect. 2.1. We apply simplifying assumptions to represent the groundwater divide at the upslope boundary, which in reality moves over time, described in Sect. 2.4.

\subsection{Field site and data}

This study focuses on a transect through the unconfined Chalk in the Pang catchment, a tributary of the River Thames in Berkshire, England (Fig. 1). The Pang and adjacent Lambourn catchments have been extensively monitored over a number of decades. The site is attractive because of the data availability, the relatively well understood regional flow paths in the saturated zone (Hughes et al., 2011; Parker, 2011), and knowledge of flow processes in the unsaturated zone from a number of field studies (notably from a site called East Ilsley, in the middle of our transect, reported by Ireson et al., 2009a, 2012; Gallagher et al., 2012). Four monitoring wells are useful for our study, Knollend Down, Malthouse, Hodcott and Compton (Table 1).

The transect of 4 monitoring wells runs along a (normally) dry valley in the Pang catchment. This is assumed to approximate a groundwater flow line on the basis of the regional water table surface described in Hughes et al. (2011). The lowermost piezometer, located at Compton, defines the lower fixed head boundary condition of the transect. Compton can be considered the start of the continuously flowing section of the River Pang - i.e. the lowermost part of the
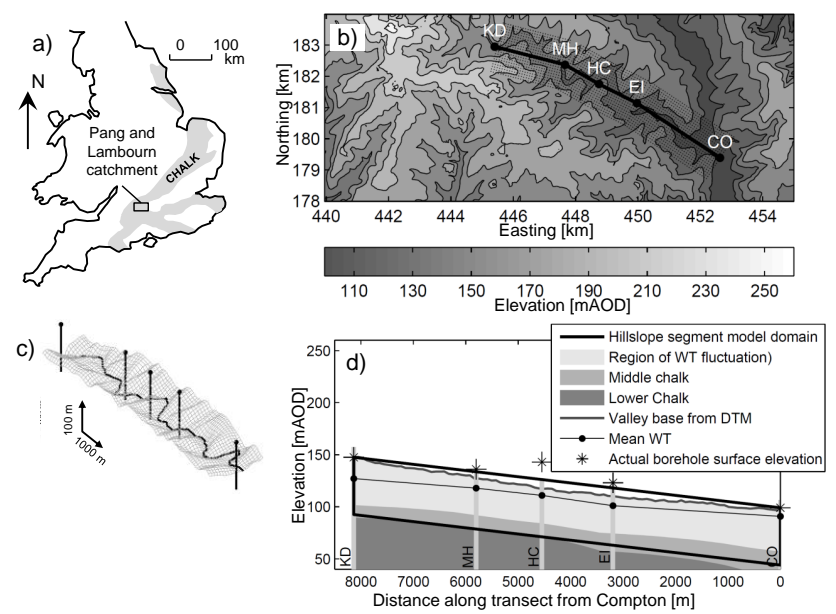

Fig. 1. The hillslope transect: (a) site location; (b) regional topography; (c) topography of transect within winding valley; (d) crosssectional profile of transect, showing model domain, observation wells and major hydrogeologic stratigraphy. The following observation wells are labelled: Knollend Down (KD), Malthouse (MH), Hodcott (HC), East Ilsley (EI) and Compton (CO).

intermittent portion of the river under normal conditions. A digital elevation model indicates that the dry valley weaves downward from Knollend Down to Compton (Fig. 1b, c). The stratigraphy across the transect was extracted from the British Geological Survey's 3-D geological model (Kessler et al., 2009), and is consistent with local borehole logs. The Chalk subdivisions are based on the broad hydrogeological classifications of middle and lower Chalk, with a distinction between the middle Chalk that is continually saturated (labelled Middle Chalk in Fig. 1d) and the middle Chalk layer that comprises the seasonally varying water table (labelled Region of WT fluctuation in Fig. 1). Estimated spatially distributed hydraulic properties for each subdivision have been determined by the British Geological Survey on the basis of field investigations (such as pumping tests, Allen et al., 1997) and regional modelling exercises (Jackson et al., 2006, 2011; Parker, 2011). As reported in Table 5.1 in Parker (2011) the mean regional values of hydraulic conductivity are $44.5 \mathrm{~m} \mathrm{day}^{-1}$ for the region of water table fluctuation, $9.5 \mathrm{~m} \mathrm{day}^{-1}$ for the underlying middle Chalk and $1 \mathrm{~m} \mathrm{day}^{-1}$ for the lower Chalk. Mean values of specific yield are 0.025 , 0.012 and 0.01 for the region of water table fluctuation, middle Chalk and lower Chalk, respectively.

\subsection{Richards' equation model}

Flow processes were simulated using Richards' equation, solved using a two-dimensional finite volume model applied on an unstructured mesh (Narasimhan and Witherspoon, 1976; Bear and Cheng, 2008, Ch. 8). The governing equation is 
Table 1. Borehole locations.

\begin{tabular}{lll}
\hline Borehole name & $\begin{array}{l}\text { Environment agency } \\
\text { station ID }\end{array}$ & $\begin{array}{l}\text { National grid } \\
\text { reference }\end{array}$ \\
\hline Knollend Down, KD & SU48/68A & SU45408295 \\
Malthouse, MH & SU48/34 & SU47668237 \\
Hodcott, HC & SU48/69 & SU48758175 \\
Compton, CO & SU57/154 & SU52637939 \\
\hline
\end{tabular}

$\frac{\partial S}{\partial t}=\int_{V} \frac{\partial \theta}{\partial t} \mathrm{~d} V=\int_{A} q \cdot \mathrm{d} A-\int_{V} s \cdot \mathrm{d} V$,

where $S$ is the volume of water $\left(\mathrm{m}^{3}\right), V$ is the cell volume $\left(\mathrm{m}^{3}\right), A$ is the area of each face of the cell $\left(\mathrm{m}^{2}\right), \theta$ is the volumetric water content within the cell $(-), t$ is time (d), $q$ is the Darcy flux $\left(\mathrm{m} \mathrm{d}^{-1}\right)$ and $s$ is a sink term $\left(\mathrm{d}^{-1}\right)$ representing uptake of water by transpiration (described below). The fluxes are given by Darcy's law, i.e.

$q=-K(\psi) \cdot\left(\frac{\partial(\psi+z)}{\mathrm{d} L}\right)$

where $\psi$ is the pressure head $(\mathrm{m}), K(\psi)$ is the hydraulic conductivity $\left(\mathrm{m} \mathrm{d}^{-1}\right), z$ is elevation above datum $(\mathrm{m})$, and $L$ is the length between two nodes $(\mathrm{m})$. The model domain is discretised into nodes and cells using a Voronoi, or perpendicular bisection, grid (Palagi and Aziz, 1994), whereby cell faces are located midway between adjacent nodes and are perpendicular to the line that bisects the two nodes. Model states $(\psi$ and $\theta$ ) are specified at nodes, and fluxes are approximated across faces. Using finite difference approximations, the flux between cells $m$ and $n, q_{m, n}$, is given by

$q_{m, n}=-\left(\frac{K\left(\psi_{m}\right)+K\left(\psi_{n}\right)}{2}\right) \cdot\left(\frac{\psi_{n}-\psi_{m}}{L_{m, n}}+\frac{z_{n}-z_{m}}{L_{m, n}}\right)$.

The hydraulic conductivity is estimated at the boundaries using the arithmetic mean (Parissopoulos and Wheater, 2006). The integral of all fluxes into cell $m$ is approximated by

$\int_{A_{m}} q \cdot \mathrm{d} A \simeq \sum_{n=1}^{f_{m}} q_{m, n} \cdot A_{m, n}$,

where $f_{m}$ is the number of faces associated with cell $m$ and $A_{m, n}$ is the cross-sectional area of the face shared by cells $m$ and $n$.

The sink term on the right hand side of Eq. (1) is approximated as

$\int_{V} s \cdot \mathrm{d} V \simeq V_{m} s_{m}$.
In order to solve Richards' equation for both saturated and unsaturated conditions, it is convenient to solve for pressure head rather water content as the dependent variable. Therefore, the left hand side of Eq. (1) can be rewritten, and approximated for cell $m$ by

$$
\begin{aligned}
\int_{V} \frac{\partial \theta}{\partial t} \mathrm{~d} V & =\int_{V}\left[C(\psi)+S_{\mathrm{s}} \cdot S_{\mathrm{e}}(\psi)\right]\left(\frac{\partial \psi}{\partial t}\right) \mathrm{d} V \\
& \simeq\left[C\left(\psi_{m}\right)+S_{\mathrm{s}} \cdot S_{\mathrm{e}}\left(\psi_{m}\right)\right] \cdot V_{m}\left(\frac{\mathrm{d} \psi_{m}}{\mathrm{~d} t}\right),
\end{aligned}
$$

where $S_{\mathrm{S}}$ is the specific storage coefficient $\left(\mathrm{m}^{-1}\right), S_{\mathrm{e}}(\psi)$ is effective saturation $(-)$, and $C(\psi)=\mathrm{d} \theta / \mathrm{d} \psi\left(\mathrm{m}^{-1}\right)$. Note, this is based on the pressure head form of Richards' equation which Tocci et al. (1997) demonstrated to be mass conservative using the solution procedure described below. Substituting Eqs. (4), (5) and (6) into Eq. (1) and rearranging we obtain a system of ordinary differential equations given by

$\frac{\mathrm{d} \psi_{m}}{\mathrm{~d} t}=\frac{\sum_{n=1}^{f_{m}} q_{m, n} \cdot A_{m, n}-V_{m} \cdot s_{m}}{\left[C\left(\psi_{m}\right)+S_{\mathrm{s}} \cdot S_{\mathrm{e}}\left(\psi_{m}\right)\right] \cdot V_{m}}$.

This system of equations is solved for $\psi(t, x, z)$ numerically in MATLAB with the stiff ordinary differential equation solver ODE15S (Shampine and Reichelt, 1997). This employs an adaptive time grid, which minimises numerical errors that have been reported for pressure-head solutions to Richards' equation (Diersch and Perrochet, 1999). This is similar to the solution procedure applied by Tocci et al. (1997), and has been used previously in other 1-D problems (Ireson et al., 2009b; Ireson and Butler, 2011). The numerical solutions were found to be stable and mass conservative.

\subsection{Hydraulic properties}

Chalk is a fractured porous medium. As well as flow through the matrix, Ireson and Butler (2011) distinguish between two types of fracture flow that can occur in unsaturated fractured porous media: preferential fracture flow and non-preferential fracture flow. Non-preferential fracture flow occurs when the local exchanges of water between fractures and matrix are rapid compared to the rate of vertical flow, and the two domains remain in pressure equilibrium. In this case, the rock can be treated as an equivalent continuum. Preferential flow occurs when flow through the fractures is too fast for local equilibrium exchange with the matrix, and in this case an equivalent continuum approach is not valid (Doughty, 1999). In the Chalk unsaturated zone preferential flow events have been observed following intense rainfall events (Ireson et al., 2009a, 2012; Ireson and Butler, 2011), but these are rare. For the period simulated in this paper, 1970-2000, the maximum recorded daily rainfall was $71.7 \mathrm{~mm}$, much lower than the events that have led to preferential fracture flow (Ireson et al., 2009a). Therefore, the effect of preferential flow was 
assumed to be negligible and the hydraulic properties of the Chalk were represented using an equivalent continuum approach (Peters and Klavetter, 1988; Doughty, 1999; Ireson et al., 2009b), where the bulk property is simply the volume weighted sum of the properties of each domain.

$\theta(\psi)=w_{\mathrm{f}} \theta^{f}(\psi)+\left(1-w_{\mathrm{f}}\right) \theta^{m}(\psi)$

$C(\psi)=w_{\mathrm{f}} C^{f}(\psi)+\left(1-w_{\mathrm{f}}\right) C^{m}(\psi)$

$K(\psi)=w_{\mathrm{f}} K^{f}(\psi)+\left(1-w_{\mathrm{f}}\right) K^{m}(\psi)$

All model parameters are defined in Table 2. The hydraulic properties of each domain (matrix and fractures) were specified using a two parameter Kosugi relationship (Kosugi, 1994, 1996), given by

$S_{\mathrm{e}}=0.5+0.5 \operatorname{erf}\left(-\frac{\left[\ln \left(\psi / \psi_{0}\right) / \sigma-\sigma\right]}{\sqrt{2}}\right)$,

$\theta=\theta_{r}+S_{\mathrm{e}}\left(\theta_{s}-\theta_{r}\right)$,

$C=\frac{\theta_{s}-\theta_{r}}{(2 \pi)^{1 / 2} \sigma(-\psi)} \exp \left(-\frac{\left[\ln \left(\psi / \psi_{0}\right)-\sigma^{2}\right]^{2}}{2 \sigma^{2}}\right)$,

$K=K_{\mathrm{s}} S_{\mathrm{e}}^{L}\left[0.5+0.5 \operatorname{erf}\left(\operatorname{erf}^{-1}\left[2 S_{\mathrm{e}}-1\right]-\frac{\sigma}{\sqrt{2}}\right)\right]$,

where $\sigma(-)$ and $\psi_{0}(\mathrm{~m})$ are the standard parameters of the Kosugi relationship. However, following Ireson et al. (2009b), these two parameters were transformed in order to make it more straightforward to scale them as a continuous function of depth. The transformed parameters define two specific points on the soil moisture retention curve, namely the values $\psi_{05}$ and $\psi_{95}$ which are the matric potentials that correspond to effective saturations, $S_{\mathrm{e}}$, of 5 and $95 \%$, respectively. These are related to the Kosugi parameters by the relationships:

$\sigma=\frac{\ln \left(\frac{\psi_{95}}{\psi_{05}}\right)}{-3.29}$,

$\psi_{0}=\frac{\psi_{05}}{e^{(1.64+\sigma) \sigma}}$.

The advantage of this approach is that the physical meaning of the parameters is clear, and scaling of these parameters with depth is fairly intuitive. The conceptual idea with the scaling here, again following Ireson et al. (2009b), is that in the shallow weathered layers there is a larger fracture volume, $w_{\mathrm{f}}(-)$, and the fracture domain comprises a range of small to large fractures, whilst the deep, consolidated Chalk contains a smaller number of only relatively large fractures.
Table 2. Richards' equation model parameters.

\begin{tabular}{lll}
\hline \multicolumn{2}{l}{ Variables } & \\
$d$ & Depth below ground surface & $\mathrm{m}$ \\
$\psi$ & Matric potential & $\mathrm{m}$ \\
$S_{\mathrm{e}}$ & Effective saturation & - \\
\hline Matrix parameters & \\
$\theta_{\mathrm{r}}^{m}$ & Residual water content & 0 \\
$\theta_{\mathrm{s}}^{m}$ & Saturated water content & 0.35 \\
$\psi_{05}^{m}$ & $\psi$ when $S_{\mathrm{e}}=0.05$, all $d$ & $-95.2 \mathrm{~m}$ \\
$\psi_{95}^{m}$ & $\psi$ when $S_{\mathrm{e}}=0.95$, all $d$ & $-14.1 \mathrm{~m}$ \\
$K_{\mathrm{S}}^{m}$ & Saturated hydraulic conductivity & $0.53 \mathrm{~mm}$ day \\
$L^{m}$ & Hydraulic conductivity exponent & 0.5 \\
\hline Fracture parameters & \\
$\theta_{\mathrm{r}}^{f}$ & Residual water content & 0 \\
$\theta_{\mathrm{s}}^{f}$ & Saturated water content & 1 \\
$\psi_{05,0}^{f}$ & $\psi$ when $S_{\mathrm{e}}=0.05$, at $d=0$ & $-40.1 \mathrm{~m}$ \\
$\psi_{05, \infty}^{f}$ & $\psi$ when $S_{\mathrm{e}}=0.05$, at $d \rightarrow \infty$ & $-1.29 \mathrm{~m}$ \\
$\psi_{95}^{f}$ & $\psi$ when $S_{\mathrm{e}}=0.95$, all $d$ & $-0.1 \mathrm{~m}$ \\
$K_{\mathrm{S}}^{f}$ & Saturated hydraulic conductivity & $4000 \mathrm{~m} \mathrm{day}-1, *$ \\
$L_{f}^{f}$ & Hydraulic conductivity exponent & 4.08 \\
\hline$D_{\text {Depth scaling parameters }}$ & \\
$w_{\mathrm{f}, 0}$ & Fracture porosity at $d=0$ & 0.12 \\
$w_{\mathrm{f}, \infty}$ & Fracture porosity at $d \rightarrow \infty$ & 0.01 \\
$Z_{\alpha}$ & Scaling parameter & $-1.4 \mathrm{~m}$ \\
$Z_{\beta}$ & Scaling parameter & $0.89 \mathrm{~m}$ \\
\hline & & \\
\hline
\end{tabular}

* This is the only parameter that was modified from Ireson et al. (2009b). Note that $K_{\mathrm{S}}^{f} \cdot w_{\mathrm{f}, \infty}=40 \mathrm{~m} \mathrm{day}^{-1}$, which is a reasonable estimate for the bulk saturated hydraulic conductivity in the Chalk.

This scaling with depth, $d(\mathrm{~m})$, is achieved using the following parametric relationships:

$w_{\mathrm{f}}=w_{\mathrm{f}, \infty}+\frac{w_{\mathrm{f}, 0}-w_{\mathrm{f}, \infty}}{1+\exp \left(Z_{\alpha}\left(d-Z_{\beta}\right)\right)}$,

$\psi_{05}^{f}=\psi_{05, \infty}^{f}+\frac{\psi_{05,0}^{f}-\psi_{05, \infty}^{f}}{1+\exp \left(-Z_{\alpha}\left(d-Z_{\beta}\right)\right)}$.

The model contains 17 parameters, summarised here in Table 2. We adopt parameter values from Ireson et al. (2009b) obtained from the field site at Warren Farm in the adjacent Lambourn catchment. The only parameter that was modified was the fracture saturated hydraulic conductivity, $K_{\mathrm{S}}^{f}$ $\left(\mathrm{mday}^{-1}\right)$. This was set to $4000 \mathrm{mday}^{-1}$, such that with a fracture porosity of $1 \%$ the bulk saturated hydraulic conductivity of the rock would be $40 \mathrm{~m} \mathrm{day}^{-1}$. This magnitude is consistent with the saturated hydraulic conductivity used in a previous groundwater model developed for the area (discussed in Parker, 2011; Jackson, 2011; Jackson et al., 2011; Jones et al., 2012). 


\subsection{Boundary conditions}

The model domain is enclosed by the four boundaries shown in Fig. 1d. An ideal hillslope for simulating flow processes would be located on a transect through a homogeneous material, along a flow line where flow is perfectly parallel with the transect (i.e. does not converge or diverge), and bounded by a fixed water table divide at the interfluve, and a fixed stage river in the valley (i.e. the classic conceptualisation of Tóth, 1963). In real catchments, such a configuration is unlikely to be found. Here we adopt idealised boundary conditions, with the hope that, at the point of interest close to the centre of the transect, the flow processes in the saturated zone are a reasonable approximation to reality. The upslope boundary poses a particular challenge. In the Pang catchment, the groundwater divide moves, as is evident from observed water table surfaces (Hughes et al., 2011; Parker, 2011), and this is likely to a be a characteristic that is common to Chalk catchments. Therefore, it is not possible to specify a no-flow boundary at some fixed interfluve location. We therefore consider a constant inflow at the upslope boundary (Knollend Down) which is downslope from the actual (moving) interfluve. The value of this inflow was established by trial and error, to give an improved fit to the observed water table elevations in the boreholes along the transect - in general, increasing the inflow leads to a steeper water table gradient along the transect. This was the only refinement of the physically based model that was performed in order to improve the fit with the observations. The value of this boundary inflow was $6 \mathrm{~m}^{2} \mathrm{~d}^{-1}$ (note, this is a flow per unit width of the aquifer). This is equivalent to the contribution from an upstream aquifer of $6 \mathrm{~km}$ length, recharged uniformly at $1 \mathrm{~mm} \mathrm{~d}^{-1}$. This magnitude therefore is not unrealistic, although in reality we would expect variations seasonally and between years as recharge rates vary and the catchment expands and contracts.

This boundary condition is implemented as a uniform lateral flux beneath the water table on the left hand boundary using the discretised form of Eq. (19) given in Eq. (20).

$$
\begin{gathered}
q_{L}=\frac{Q_{L}}{\int_{z_{\mathrm{b}}}^{h} \mathrm{~d} A}, \\
q_{L, i}=\frac{Q_{L}}{\sum_{i=1}^{N} A_{i}},
\end{gathered}
$$

where $Q_{L}$ is the boundary inflow $\left(\mathrm{m}^{2} \mathrm{~d}^{-1}\right), q_{L}$ is the flux into each saturated (i.e. $\psi>0)$ cell $\left(\mathrm{m} \mathrm{d}^{-1}\right), z_{\mathrm{b}}$ is the elevation of the base of the aquifer $(\mathrm{m}), h$ is the elevation of the water table (m) which is a function of time, $A$ is the cross-sectional area per unit width $(\mathrm{m})$ and the index $i(-)$ refers to all submerged cells on the left hand boundary, from the base of the aquifer $(i=1)$ to the water table $(i=N)$. Above the water table, a zero flux boundary is applied on the left hand side.

The right hand, or downslope, boundary, at Compton, is located at the point where the intermittently dry valley meets the permanently flowing River Pang. A fixed head boundary condition was used. Simulations were found to be insensitive to water level fluctuations on the boundary, and therefore the mean water level from the Compton borehole was used to define this boundary, that is $h_{R}=85 \mathrm{~m}$.

The lower boundary (i.e. the base of the actively flow portion of the aquifer) is approximately located at the interface between the middle and lower Chalk, where the hydraulic conductivity drops significantly. For simplicity, this is treated as an impermeable boundary and a no flow boundary condition is used.

Finally, for the upper boundary at the ground surface, spatially uniform infiltration of rainfall is applied as a specified flux boundary. An absence of surface runoff has been observed in the Chalk (Foster, 1975; Ragab et al., 1997) and hence runoff and ponding are ignored. Land cover is grassland over the hillslope, and interception is considered to be negligible compared with errors in the rainfall and potential evaporation measurements. Rainfall is given by a daily rainfall time series from a local rain gauge (Environment Agency gauge 268812 located approximately $6 \mathrm{~km}$ from the transect). The vertical distribution of evapotranspiration is assumed to be entirely transpiration losses from the root zone, and is estimated using the Feddes model (Feddes et al., 1976), driven by monthly MORECS (Met Office Rainfall and Evaporation Calculation System) (location 159, Thompson et al., 1981) potential evaporation (PE) linearly interpolated onto a daily time step.

The sink term in cell $m$ due to evapotranspiration through plant roots, $s_{m}\left[\mathrm{~d}^{-1}\right]$, is obtained using the root-extraction function,

$s_{m}=f\left(\psi_{m}\right) g\left(z_{m}^{\prime}\right) \frac{E(t) A_{\mathrm{s}}}{V_{m}}$,

where $z_{m}^{\prime}(\mathrm{m})$ is the depth of the centroid of the cell below the ground surface, $E(t)\left(\mathrm{m} \mathrm{d}^{-1}\right)$ is the potential evapotranspiration rate, $f\left(\psi_{m}\right)(-)$ is the water stress function, $g\left(z_{m}^{\prime}\right)$ $(-)$ is the normalised root density, $A_{\mathrm{S}}$ is the surface area over which the evaporation flux was applied and $V_{m}$ is the volume of the cell. The water stress function, ignoring the effect of anaerobiosis (that is suppression of evaporation under saturated conditions), is given by

$$
f(\psi)= \begin{cases}1, & \psi>\psi_{d} \\ 1-\frac{\psi-\psi_{d}}{\psi_{w}-\psi_{d}}, & \psi_{d} \geq \psi>\psi_{w} \\ 0, & \psi_{w} \geq \psi\end{cases}
$$

where $\psi_{d}(\mathrm{~m})$ and $\psi_{w}(\mathrm{~m})$ are matric potential thresholds corresponding to the point below which water stress commences and the wilting point, respectively. Thresholds values of $\psi_{d}=-4 \mathrm{~m}$ and $\psi_{w}=-150 \mathrm{~m}$ were used (Feddes et al., 1976). 


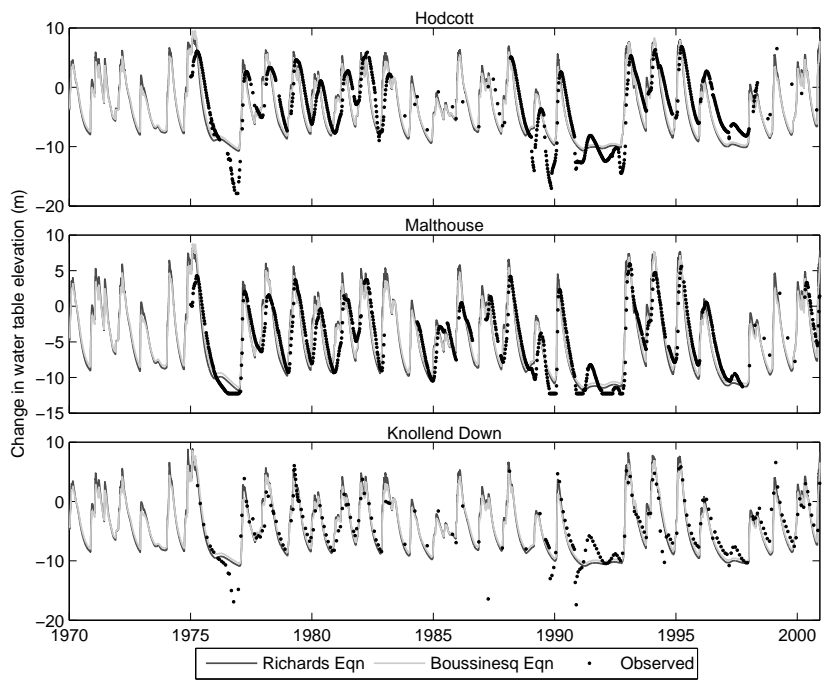

Fig. 2. Performance of Richards' equation model at simulating change in water table elevation. Performance of the Boussinesq model is also shown, validating the premise of the model emulation strategy.

The root density, $\rho_{\mathrm{r}}\left(\mathrm{m} \mathrm{m}^{-3}\right)$, is assumed to be exponentially distributed with depth, defined by

$\rho_{\mathrm{r}}=\frac{\exp \left(-z^{\prime} / L\right)}{L}$

where $L(\mathrm{~m})$ is a parameter representing the depth above which $63 \%$ of roots are present, taken as $0.2 \mathrm{~m}$ (Ireson et al., $2009 \mathrm{~b})$. It is assumed that the root systems are uniform along the transect. The normalised root density, $g\left(z_{m}^{\prime}\right)(-)$, expresses the proportion of the total root system present within the particular depth horizon enclosed by cell $m$. Cells in the mesh that was used were deliberately arranged in columns, and we adopt here the indices $i$ and $j$ to refer to cells within a particular column. Hence, in discrete notation, $g\left(z_{i}^{\prime}\right)$ is given by

$g\left(z_{i}^{\prime}\right)=\frac{\rho_{\mathrm{r}, i} \cdot V_{i}}{\sum_{j=1}^{n} \rho_{\mathrm{r}, j} V_{j}}$.

Equations (21) and (24) can be combined to give

$s_{i}=\frac{f\left(\psi_{i}\right) \cdot \rho_{\mathrm{r}, i} \cdot E(t) \cdot A_{\mathrm{s}}}{\sum_{j=1}^{n} \rho_{\mathrm{r}, j} V_{j}}$

and actual evaporation, $\mathrm{AE}\left(\mathrm{m} \mathrm{d}^{-1}\right)$ can be found from

$\mathrm{AE}=\frac{\sum_{i=1}^{n} s_{i} \cdot V_{i}}{A_{\mathrm{S}}}$.

\subsection{Initial conditions}

The initial condition was based on the steady-state water table response to a constant recharge rate of $1 \mathrm{~mm} \mathrm{~d}^{-1}$, and a

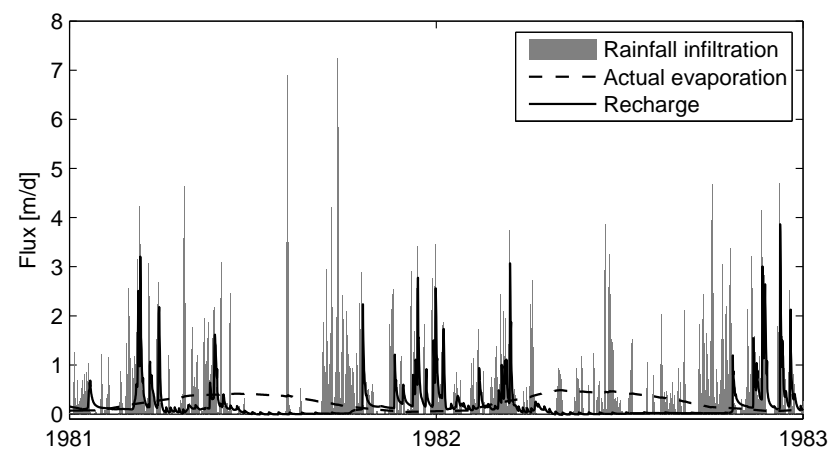

Fig. 3. Simulated recharge compared with infiltration and actual evaporation.

uniform pressure in the unsaturated zone above the hydrostatic capillary fringe of $-2 \mathrm{~m}$. The initial condition applied on 1 January 1970, and the first $5 \mathrm{yr}$ are considered a warm up period to eliminate the impact of this arbitrary initial condition.

\subsection{Model performance}

The performance of the model in reproducing the observed behaviour of the water table is shown in Fig. 2. Overall, the performance at Malthouse is the best. Here, the level of the annual peak and trough of the water table is normally captured quite well, as is the shape of the hydrographs with some exceptions. The observed response appears to lag the simulated response consistently, which is a concern. At Hodcott and Knollend Down there are problems during the drought of 1976/1977 which might be explained by local pumping that occurred to augment river flows during this period (Morel, 1980). This does not show up at Malthouse since the observations bottom out, as can be seen in 1976/1977 and in the early 1990s. Overall, given the necessary simplifying assumptions in constructing the domain and boundaries of the transect, the fact that model was essentially uncalibrated, and uncertainty in the driving rainfall and evaporation data, this is a plausible physically based model of recharge and water table response in the Chalk at the centre of the transect.

Figure 3 illustrates the simulated recharge fluxes as compared with rainfall and actual evaporation, for the years 1981 and 1982. High intensity and sustained summer rainfall events typically result in either a negligible or very small recharge response. Conversely, in the winter months when the soil and unsaturated zones are wetter and the unsaturated thickness is smaller, rainfall events are converted into significant recharge responses. This shows that the complex and non-linear recharge processes in the Chalk that have been described elsewhere (Ireson et al., 2009a; Ireson et al., 2009b) are captured by the model.

Figure 4 shows hydraulic head profiles in the unsaturated and saturated zones throughout a typical year, with the lower 

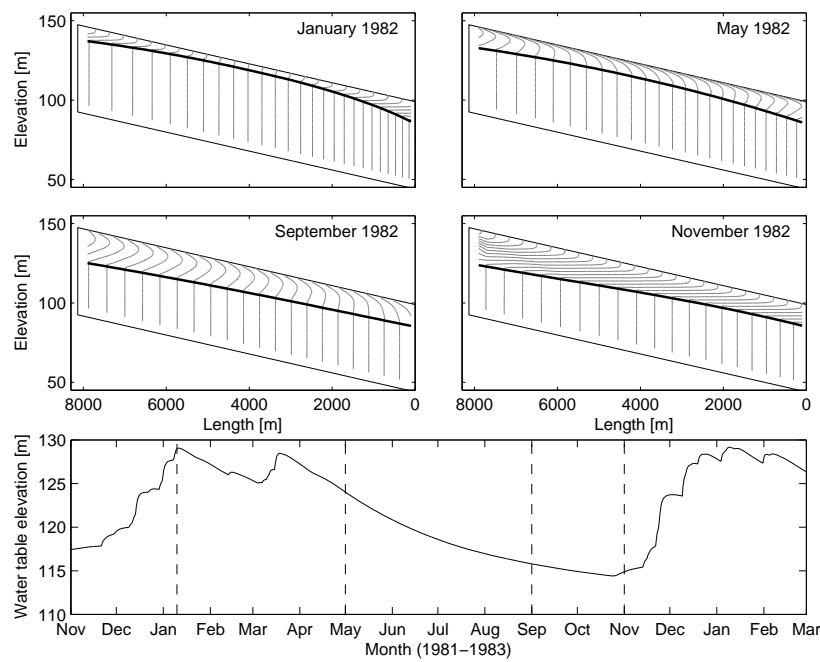

Fig. 4. Hydraulic head distribution in the unsaturated and saturated zones, through a typical year (note exaggerated vertical-scale in transect plots).

plot showing the seasonal water table response. Flow lines are effectively perpendicular to the head contours plotted. The flow direction changes very sharply between the unsaturated and saturated zones, as the fractures, with a high air entry value (i.e. thin capillary fringe) and high hydraulic conductivity, rapidly empty. In the saturated zone flow is always sub-horizontal, always downslope, and the rate can be inferred from the distance between contours. In the unsaturated zone flow directions are more complex. Despite appearances in Fig. 4 due to the scale distortion, lateral fluxes in the unsaturated zone are negligible (around four orders of magnitude smaller than the vertical fluxes). However, the vertical fluxes switch direction depending on when infiltration or evaporation dominate (winter and summer, respectively), with zero flux planes developing in the profile, as described by Wellings (1984) and Ireson et al. (2009b).

\section{Simplified model}

\subsection{Simplified hillslope model}

In this section we report a simple modelling approach which was applied to try to reproduce the behaviour of the complex physically based model described above. The approach is similar to the integral balance method suggested by Duffy (1996), who posed the question "Can low dimensional dynamic models of hillslope-scale and catchment-scale flow processes be formulated such that the essential physical behavior of the natural system is preserved?" Once a detailed numerical model has been established, the states within and boundary fluxes between particular sub-volumes of the model domain can be obtained by integration. The final emulation step is to develop simple relationships that can reproduce the fluxes between stores. Duffy reduced the complexity of a hypothetical hillslope model into a single saturated store and a single unsaturated store, in order to simulate total groundwater storage and discharge. Here we are interested in groundwater recharge, rather than discharge, and therefore we will split the hillslope domain into a number of vertical columns in the unsaturated zone, overlying a single, horizontally discretised saturated zone. The assumption that flow is vertical in the unsaturated zone and horizontal in the saturated zone is justified by the results from the detailed model. Horizontal saturated flow is simulated using the 1-D (horizontal) Boussinesq equation, as in Eq. (27).

$S_{\mathrm{y}} \frac{\partial h}{\partial t}=\frac{\partial}{\partial x}\left(K_{\mathrm{s}}\left(h-z_{\mathrm{b}}\right) \frac{\partial h}{\partial x}\right)+R$,

where $S_{\mathrm{y}}$ is specific yield (-), assumed equal to the fracture porosity $(1 \%), K_{\mathrm{S}}$ is the bulk rock saturated hydraulic conductivity $\left(\mathrm{m} \mathrm{d}^{-1}\right.$ ) (in this case $40 \mathrm{md}^{-1}$ ) and $R$ is the time varying recharge flux $\left(\mathrm{m} \mathrm{d}^{-1}\right)$.

A preliminary model run was undertaken to ensure that the 1-D Boussinesq equation is consistent with the Richards' equation representation of the saturated zone (i.e. that the Dupuit assumptions are valid, Fetter, 1994, p. 163). Recharge fluxes, $R(t, x)$, were extracted from the two-dimensional Richards' equation model and used to drive a Boussinesq equation model, with boundary conditions:

$$
\begin{array}{rl}
h=h_{R} & x=0 ; t>0 \\
-K_{\mathrm{s}}\left(h-z_{\mathrm{b}}\right) \frac{\partial h}{\partial x}=6 x & =L ; t>0,
\end{array}
$$

where $L$ is the length of the model domain (m) (i.e. $x=L$ is the left hand boundary).

The initial condition in $h$ was identical to that employed in the Richards' equation model for the initial water table elevation. This 1-D model was solved numerically using the same procedure described above, with MATLAB ODE15S. As shown in Fig. 2, the performance of the Boussinesq model was nearly identical to the Richards' equation model. This validates the Dupuit assumptions for this particular problem, and demonstrates that if we couple our simple recharge model to the Boussinesq equation we should be able to simulate the hillslope-scale processes correctly, assuming of course that the recharge model is correct.

\subsection{Simple recharge model}

The next step in this process is to replace the unsaturated zone representation with a simple conventional recharge model, similar to that presented by Rushton (2005). The states, fluxes and parameters used in the recharge model are given in Table 3 and a schematic diagram of the model is given in Fig. 5.

The model is solved as an initial value problem, with an explicit time stepping method, with index $j$ referring to the 


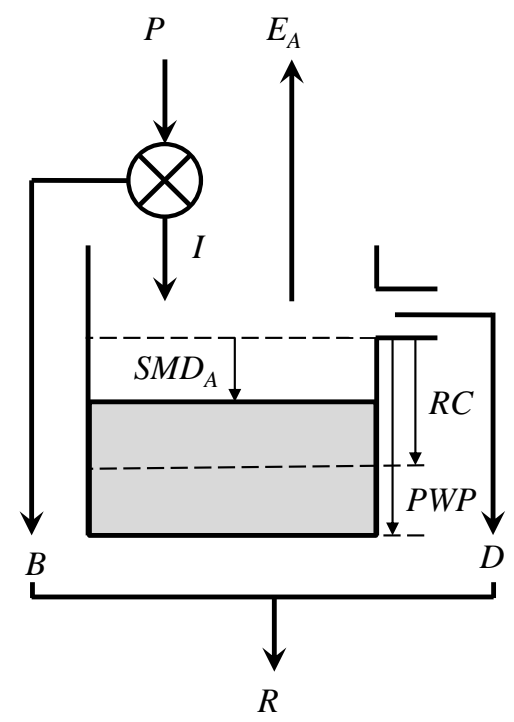

Fig. 5. Structure of the conventional recharge model.

current time step. An initial soil moisture deficit, $\mathrm{SMD}_{A, 1}$ is specified, and then Eqs. (29) to (34) are solved in sequence, in a time loop from $j=2$ to $n_{T}$, where $n_{T}$ is the number of time steps.

$B_{j}= \begin{cases}0 & \left(P_{j}-\mathrm{TH}\right) \leq 0 \\ B F\left(P_{j}-\mathrm{TH}\right) & \left(P_{j}-\mathrm{TH}\right)>0\end{cases}$

$\operatorname{SMD}_{P, j}=\operatorname{SMD}_{A, j-1}-\left(P_{j}-B_{j}\right)+E_{\mathrm{P}, j}$

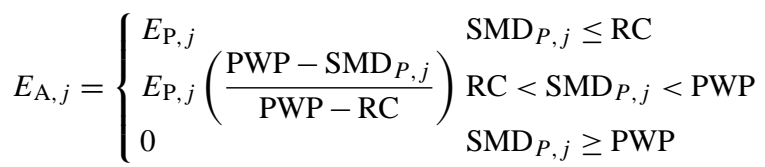

$D_{j}= \begin{cases}-\operatorname{SMD}_{P,} & \operatorname{SMD}_{P, j}<0 \\ 0 & \operatorname{SMD}_{P, j} \geq 0\end{cases}$

$\operatorname{SMD}_{A, j}=\left\{\begin{array}{lr}0 & \operatorname{SMD}_{P, j}<0 \\ \operatorname{SMD}_{A, j-1}-\left(P_{j}-B_{j}\right)+E_{\mathrm{A}, j} & \operatorname{SMD}_{P, j} \geq 0\end{array}\right.$

$R_{j}=D_{j}+B_{j}$

This model was coupled with the Boussinesq model for the hillslope transect, such that recharge was uniform across the entire transect. This was coded-up in FORTRAN using a simple explicit solution scheme, with a time step sufficiently small to give acceptably small truncation errors (i.e. reducing the time step further had no detectable impact on
Table 3. Simple model states, fluxes and parameters.

\begin{tabular}{lll}
\hline \multicolumn{2}{l}{ State variables } & \\
$\mathrm{SMD}_{A}$ & Soil moisture deficit & $(\mathrm{m})$ \\
$\mathrm{SMD}_{P}$ & Potential soil moisture deficit & $(\mathrm{m})$ \\
\hline Fluxes & & \\
$P$ & Rainfall* & $\left(\mathrm{m} \mathrm{d}^{-1}\right)$ \\
$E_{\mathrm{P}}$ & Potential evaporation* & $\left(\mathrm{m} \mathrm{d}^{-1}\right)$ \\
$E_{\mathrm{A}}$ & Actual evaporation & $\left(\mathrm{m} \mathrm{d}^{-1}\right)$ \\
$I$ & Infiltration & $\left(\mathrm{m} \mathrm{d}^{-1}\right)$ \\
$D$ & Soil drainage & $\left(\mathrm{m} \mathrm{d}^{-1}\right)$ \\
$B$ & Bypass flow & $\left(\mathrm{m} \mathrm{d}^{-1}\right)$ \\
$R$ & Recharge & $\left(\mathrm{m} \mathrm{d}^{-1}\right)$ \\
& $*$ driving variables & \\
\hline Parameters & \\
RC & Root constant & $\left(\mathrm{m}^{*}\right)$ \\
$\mathrm{PWP}$ & Permanent wilting point & $(\mathrm{m})$ \\
$\mathrm{BF}$ & Bypass fraction & $(-)$ \\
$\mathrm{TH}$ & Bypass threshold & $\left(\mathrm{m} \mathrm{d}^{-1}\right)$ \\
\hline
\end{tabular}

the model output), and was thus very computationally efficient, allowing us to search the parameter space effectively using a Monte Carlo method. There are four parameters in the recharge model, and $10^{4}$ realisations were used. Stratified parameter sampling was adopted such that one-third of realisations had no bypass $(\mathrm{BF}=0, \mathrm{TH}=0)$, one-third had bypass with no threshold $(\mathrm{BF}>0, \mathrm{TH}=0)$, and one-third had bypass over some threshold $(\mathrm{BF}>0, \mathrm{TH}>0)$. These combinations result in three separate model structures, and the sampling gives an equal weight to each structure. This allows us to explore all of the model configurations considered by Rushton and Ward (1979), who were only able to consider 9 parametric combinations due to the limitations on computing power at that time. Parameters were sampled from uniform random distributions as follows: $10 \mathrm{~mm} \leq \mathrm{RC} \leq 2000 \mathrm{~mm}$; $10 \mathrm{~mm} \leq(\mathrm{PWP}-\mathrm{RC}) \leq 2000 \mathrm{~mm} ; 0<\mathrm{BF} \leq 0.3 ; 0<\mathrm{TH} \leq$ $30 \mathrm{~mm} \mathrm{~d}^{-1}$. The objective function minimised the root mean squared error of the water table simulated by the simple and benchmark models, at a point in the centre of the hillslope transect in order to minimise the impact of the lateral boundary conditions. An objective function threshold of $0.98 \mathrm{~m}$ was selected subjectively, on the basis that all realisations with an objective function value lower than this visually fitted the benchmark model well and were thus considered behavioural.

\subsection{Simple model results}

The performance of the simple model in reproducing the benchmark water table is shown in Fig. 6a. Overall, the performance is surprisingly good. The most noticeable weakness is during the drought in the mid-1970s, and dry periods in the late 1980s and early 1990s. However, even during these periods these errors are small, especially compared 
a)
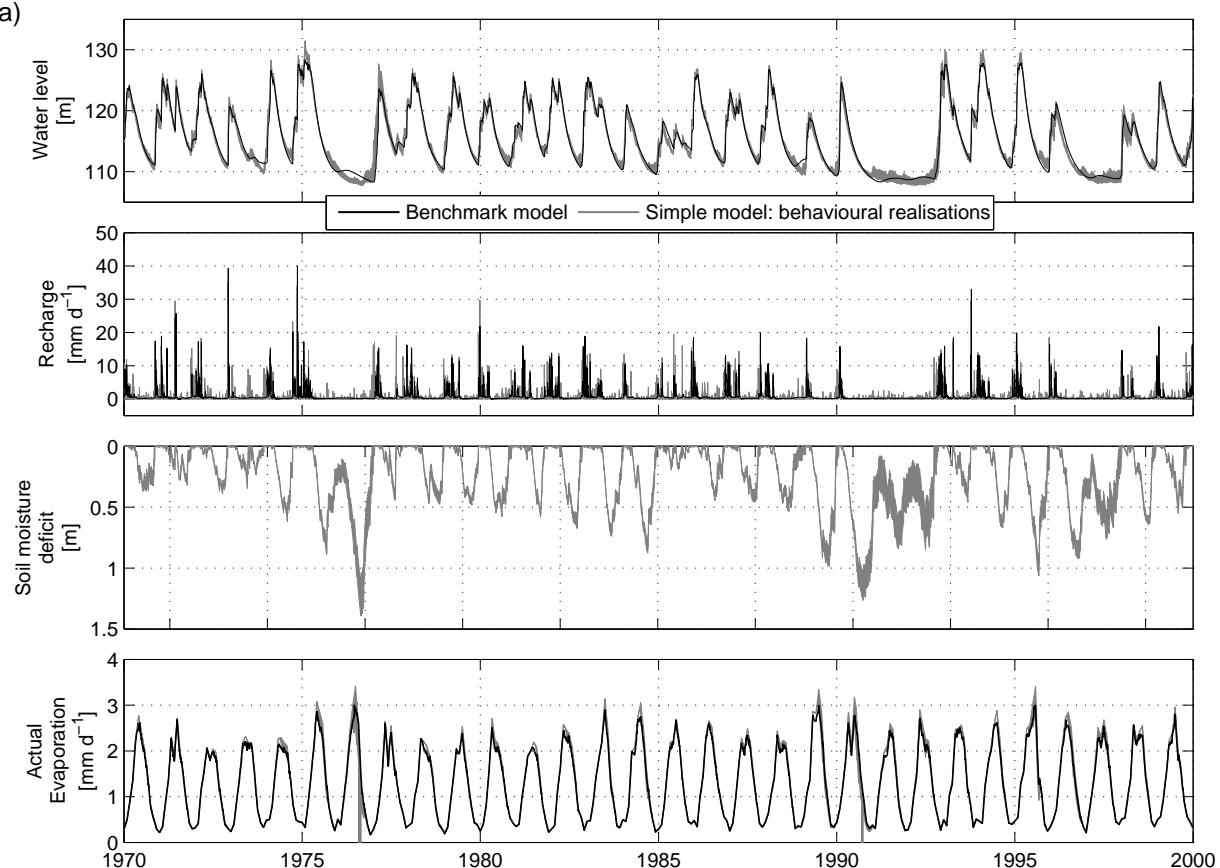

b)

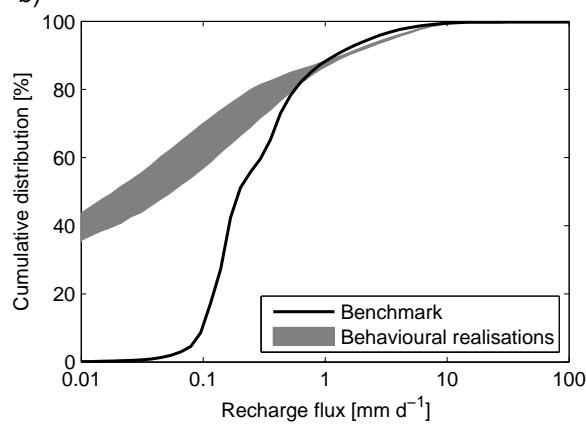

Key to dotty plots:

- No bypass $\quad$ Simple bypass

- Threshold bypass $\quad \bullet$ Bimple bypavioural realisations c)
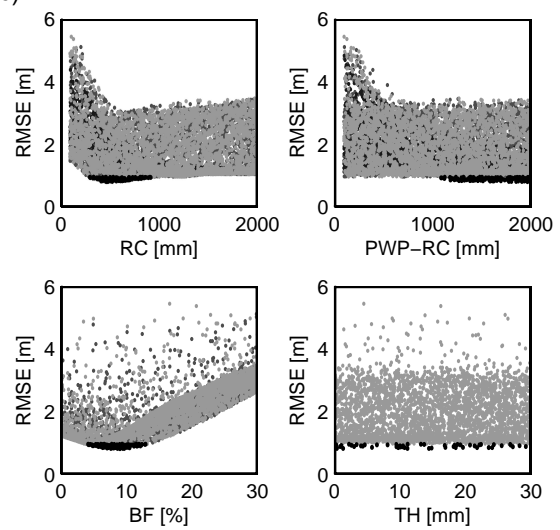

Fig. 6. Results from the simple model using a daily time step. (a) Performance of the simple model (grey lines) in reproducing benchmark (black lines) water table, recharge, soil moisture status and actual evaporation; (b) cumulative distribution of recharge fluxes; (c) parameter identifiability.

with errors between the benchmark model and observations. The global minimum objective function from $10^{4}$ realisations was 0.83 , and 139 realisations were behavioural. All of the behavioural model realisations are plotted and all provide good fits to the benchmark water table (equifinality). Parameter identifiability is shown in the dotty plots in Fig. 6c. The bypass threshold, $\mathrm{TH}$, is completely insensitive and therefore should not be included in the model, since it requires an additional parameter that results in no improvement. The bypass fraction, $\mathrm{BF}$, is sensitive, with an optimum value in the range $4.3-13.0 \%$. The root constant, $\mathrm{RC}$, is also relatively sensitive, with an optimal value in the range $300-920 \mathrm{~mm}$. The difference between the permanent wilting point and the root constant, PWP-RC, is less sensitive, but larger values $(>1000 \mathrm{~mm})$ are subtly better.

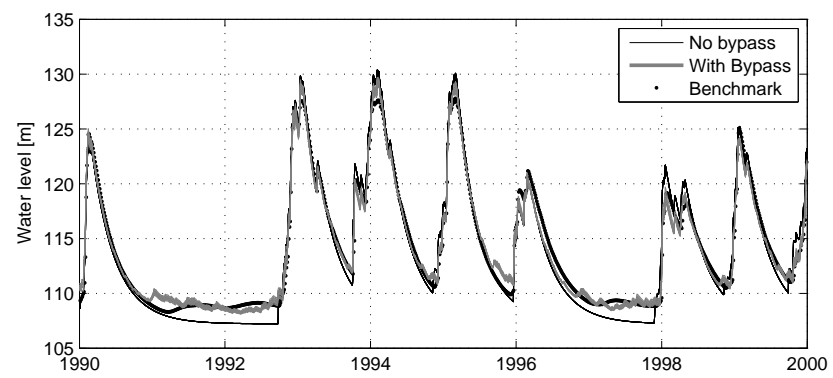

Fig. 7. Optimal water table simulations with the simple model with and without bypass recharge. 
a)
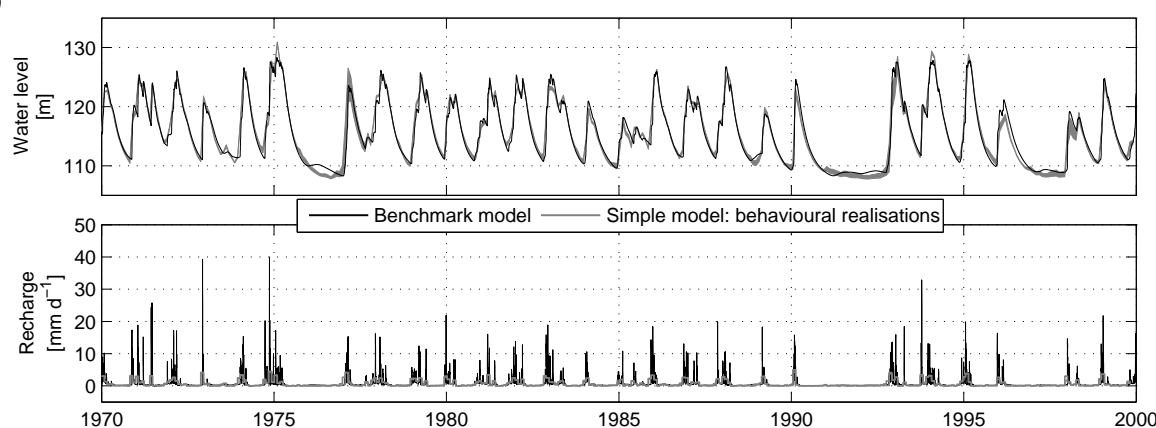

b)

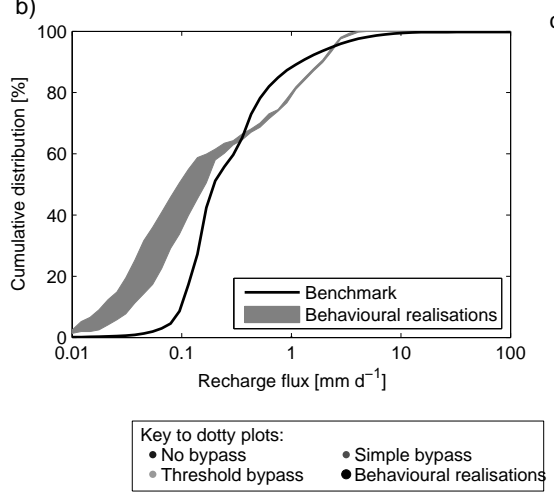

c)
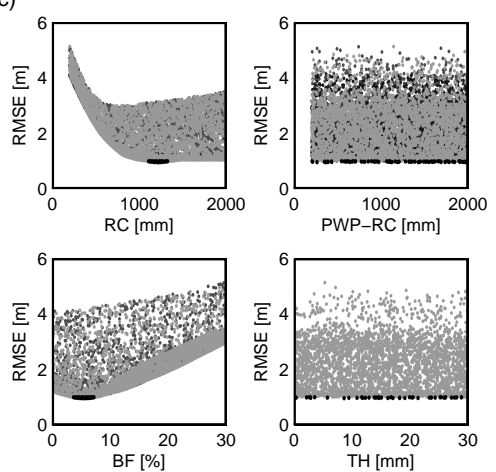

Fig. 8. Results from the simple model using a monthly time step. (a) Performance of the simple model (grey lines) in reproducing benchmark (black lines) water table, recharge, soil moisture status and actual evaporation; (b) cumulative distribution of recharge fluxes; (c) parameter identifiability.

Figure 6a also shows recharge and actual evaporation simulated by the simple and benchmark models, as well as soil moisture deficit, SMD, simulated with the simple model. These variables did not influence the calibration and are an additional test of the overall coherence of the simple model. SMD values typically reach around $0.5 \mathrm{~m}$ in the summer, reaching larger values in dry years (around $1.2 \mathrm{~m}$ in 1976). If the porosity of the Chalk is around $40 \%$, then a SMD of $1.2 \mathrm{~m}$ is equivalent to completely draining $3 \mathrm{~m}$ of Chalk. Since we know that the Chalk matrix holds water at high suctions, it is very unlikely to ever drain completely. This therefore implies that a depth of Chalk significantly greater than $3 \mathrm{~m}$ is supplying water for summer evaporation, which is consistent with the deep zero flux planes hypothesized by Wellings (1984) and simulated to depths of $6-7 \mathrm{~m}$ by Ireson et al. (2009b). Simulated actual evaporation tends to be somewhat higher in the summer in the simple model as compared with the benchmark model. In 1976, some of the behavioural model realisations appear to dry the soil to wilting point, with evaporation rates dropping to zero for some time. To better compare the recharge signals, Fig. $6 \mathrm{~b}$ shows the distribution of recharge fluxes simulated by each model. It can be clearly seen that whilst the model does a reasonable job of reproducing higher recharge rates $\left(R>1 \mathrm{~mm} \mathrm{~d}^{-1}\right)$, the simple model (i) overestimates the low recharge rates; and (ii) predicts no recharge (or strictly $R<0.01 \mathrm{~mm} \mathrm{~d}^{-1}$ ) for about $40 \%$ of the time. In the benchmark model, there is always some small amount of recharge from slow drainage of the unsaturated zone (discussed by Ireson et al., 2009b). However, during the summers, and especially during the droughts of the mid-1970s and early 1990s, the simple model is unable to simulate slow drainage from the soil and unsaturated zone which, in reality, sustains recharge rates and water levels. Instead, the simple model compensates for this by using bypass rainfall events, which are visible in the recharge signal during these periods. Almost all of these events are not physically realistic, but they do enable the model to transmit enough water down to the water table to maintain higher summer water levels. The calibration thus tailors the bypass fraction to optimise this summer response. This is clearly demonstrated in Fig. 7 where the 10 optimal model realisations with and without bypass are compared. Without bypass, the model is unable to simulate the water table troughs, especially during drought conditions, and model performance is worse overall. Therefore, whilst this model performs well, the physical mechanisms are not correct. Note that if there is no soil moisture deficit, all rainfall in excess of potential evaporation is passed directly to the water table, so bypass becomes irrelevant. As a result, in the winter, when the soils are wet and SMD is frequently zero, the effect of bypass is minimal. 
It is also interesting to look at how the same simple model would perform if applied on a monthly time step. Groundwater models tend to be run on monthly time steps, so this is a more realistic test of how simple recharge models might be applied to real problems. Monthly simulations were run by (i) calculating the daily recharge rate as before, (ii) accumulating the simulated daily recharge rates to monthly recharge rates, and (iii) running the Boussinesq equation model on a monthly time step. The results are shown in Fig. 8 (note that since the recharge calculation is still daily, soil moisture and actual evaporation are unchanged and hence not replotted). There is a small decline in performance of the simulated water table, indicated by an increase in the global minimum objective function value (0.96, up from 0.83 for the daily simulations), and in a decrease in the number of behavioural realisations ( 82 from $10^{4}$, down from 139 for the daily simulation). However, there is no visible decline in the performance, as shown in Fig. 8a. However, the simulated recharge time series in Fig. 8a and cumulative distribution in Fig. $8 \mathrm{~b}$ appear significantly improved. This is because, when the recharge rates are accumulated onto a monthly time step, all of the individual summer bypass events noted previously are lumped together and, again due to the calibration, approximately make up the slow drainage from the more physically realistic model. Unsurprisingly, the optimal parameter ranges and the parameter identifiability are different in the monthly model configuration, as shown in Fig. 8c. Again the bypass threshold, TH, can be eliminated as unnecessary. Again the bypass fraction, $\mathrm{BF}$, is the most sensitive parameter, but now takes a somewhat lower value, in the range of $3.7-7.2 \%$. The root constant, $\mathrm{RC}$, has an optimal value in the range 1100 $1320 \mathrm{~mm}$, but in fact performance does not decline very significantly for larger values. Finally the difference between the permanent wilting point and root constant, $\mathrm{PWP}-\mathrm{RC}$, is now completely insensitive.

\section{Conclusions}

In this study we have applied a physically based model for the Chalk unsaturated and saturated zone based on Richards' equation with dual permeability, equivalent continuum properties, to a hillslope transect. Under certain necessary simplifying assumptions about the model domain, and with minimal calibration or refinement, the model performance was broadly consistent with transient field observations of water levels in monitoring wells. This model is highly computationally demanding, and consequently wider application of this model is impractical for anything other than research purposes. This motivates the need for a simplified model that can emulate the simulated responses.

A simple conventional recharge model (after Rushton, 2005) was rigorously tested against the benchmark, physically based model. The calibrated simple model performed surprisingly well at reproducing the water table response.
However, on close examination of the recharge signal simulated by the simple model, it was apparent that this is not consistent with our mechanistic understanding of the recharge processes. In the simple model, bypass flow was responsible for sustaining recharge and higher groundwater levels during the summer months, when soil moisture deficits prevented any drainage from the soil. However, previous work (Price et al., 2000; Ireson et al., 2009b) has suggested that slow drainage from the unsaturated zone of the Chalk is continuous throughout the year, and sustains recharge, even during drought conditions. Thus, slow drainage, not bypass flow, sustains summer water levels. Moreover, the nature of bypass flow in the Chalk unsaturated zone has been explored (e.g. Lee et al., 2006; Ireson et al., 2009a, 2012; and Ireson and Butler, 2011, to name only some of the more recent studies). In a $3 \mathrm{yr}$ record at the study site used in this paper, Ireson and Butler (2011) observed that 18 out of a total of 536 rainfall events led to a recognisable bypass recharge response at the East Ilsley monitoring well. Only rainfall over a threshold in volume and intensity, also dependent on antecedent soil moisture, led to bypass recharge. By contrast, in the modelling exercise in this paper, we found that a rainfall intensity threshold did not improve the model performance, and thus every single rainfall event results in bypass recharge. On the basis of these two significant inconsistencies, we conclude that the simple recharge models used widely in operational groundwater models are providing the right answers (especially those run on a monthly time step), but for the wrong reasons. This explains why conventional recharge models for the Chalk that apply a fixed bypass fraction have tended to work well. Typically $15 \%$ bypass has been used, dating back to Smith et al. (1970). Our study suggests a lower value may be better (we found around $5 \%$ to be optimal on a monthly time step), though this is likely to be a function of the site specific properties of the Chalk matrix and fractures. Therefore, for assessment of water resources in an average year, the existing models may be fit for purpose. However, these models may not be able to predict adequately the water table response under extreme wet or dry conditions. High intensity rainfall events have lead to significant summer recharge responses (Lee et al., 2006; Ireson and Butler, 2011) with the potential to cause rapid flooding, and to drive contaminants into the aquifers. Such responses could not be simulated with the existing models. Above average rainfall sustained over multiple months has lead to groundwater flooding (Hughes et al., 2011). Under such conditions we might expect the buffering capacity of the soil/unsaturated zone to be underestimated by the simple model, since with no soil moisture deficit all effective rainfall is passed directly to the water table as recharge. Whether this is a significant problem remains to be seen. Finally during extreme drought conditions, we would expect the discrepancy between slow drainage of the unsaturated zone and bypass flow to become exaggerated. 
Acknowledgements. This work was supported by the UK Natural Environment Research Council's Flood Risk from Extreme Events program. We acknowledge the Centre for Ecology and Hydrology and the British Geological Survey who supplied field data. We are grateful to a number of colleagues for discussion and ideas, including Howard Wheater, Denis Peach, Andrew Hughes, Chris Jackson, Thalia Vounaki and Simon Parker. We are also very grateful to two anonymous reviewers whose comments have significantly improved this paper.

Edited by: I. Neuweiler

\section{References}

Allen, D. J., Brewerton, L. J., Coleby, L. M., Gibbs, B. R., Lewis, M. A., MacDonald, A. M., Wagstaff, S. J., and Williams, A. T.: The physical properties of major aquifers in England and Wales, British Geological Survey, Technical report WD/97/34, 1997.

Allen, R., Pereira, L., Raes, D., and Smith, M.: Crop evapotranspiration-Guidelines for computing crop water requirements-FAO Irrigation and drainage paper 56, FAO, Rome 300, 6541, 1998.

Bear, J. and Cheng, A. H. D.: Modeling Groundwater Flow and Contaminant Transport, Springer, 2008.

Bradford, R. B., Ragab, R., Crooks, S. M., Bouraoui, F., and Peters, E.: Simplicity versus complexity in modelling groundwater recharge in Chalk catchments, Hydrol. Earth Syst. Sci., 6, 927937, doi:10.5194/hess-6-927-2002, 2002.

Brouyère, S.: Modelling the migration of contaminants through variably saturated dual-porosity, dual-permeability Chalk, J. Cont. Hydrol., 82, 195-219, 2006.

Brouyère, S., Dassargues, A., and Hallet, V.: Migration of contaminants through the unsaturated zone overlying the Hesbaye chalky aquifer in Belgium: a field investigation, J. Cont. Hydrol., 72, 135-164, 2004.

Brunner, P., Doherty, J., and Simmons, C. T.: Uncertainty assessment and implications for data acquisition in support of integrated hydrologic models, Water Resour. Res., 48, W07513, doi:10.1029/2011WR011342, 2012.

Butler, A. P., Hughes, A. G., Jackson, C., Ireson, A., Parker, S., Wheater, H., and Peach, D.: Advances in modelling groundwater behaviour in chalk catchments, in: Groundwater Resources Modelling: A Case Study from the UK, edited by: Shepley, M. G., Whiteman, M. I., Hulme, P. J., and Grout, M. W., No. 364, Geological Society, London, Special Publications, 113-127, 2012.

Cross, G. A., Rushton, K. R., and Tomlinson, L. M.: The east kent chalk aquifer during the 1988-92 drought, J. IWEM, 37-48, 1995.

Cuthbert, M.: An improved time series approach for estimating groundwater recharge from groundwater level fluctuations, Water Resour. Res., 46, W09515, doi:10.1029/2009WR008572, 2010.

Doughty, C.: Investigation of conceptual and numerical approaches for evaluating moisture, gas, chemical and heat transport in fractured unsaturated rock, J. Cont. Hydrol., 38, 69-106, 1999.

Duffy, C.: A two-state integral-balance model for soil moisture and groundwater dynamics in complex terrain, Water Resour. Res., 32, 2421-2434, 1996.
Diersch, H. J. G. and Perrochet, P.: On the primary variable switching technique for simulating unsaturated-saturated flows, Adv. Water Res., 23, 271-301, 1999.

Ebel, B. A. and Loague, K.: Physics-based hydrologic-response simulation: Seeing through the fog of equifinality, Hydrol. Process, 20, 2887-2900, 2006.

Feddes, R. A., Kowalik, P., Kolinska-Malinka, K., and Zaradny, H.: Simulation of field water uptake by plants using a soil water dependent root extraction function, J. Hydrol., 31, 13-26, 1976.

Fetter, C. W.: Applied Hydrogeology, Macmillan, New York, 3rd Edn., 1994.

Finch, J. W.: Estimating direct groundwater recharge using a simple water balance model-sensitivity to land surface parameters, J. Hydrol., 211, 112-125, 1998.

Finch, J.: Estimating change in direct groundwater recharge using a spatially distributed soil water balance model, Q. J. Eng. Geol. Hydroge., 34, 71-83, 2001.

Foster, S. S. D.: The Chalk groundwater tritium anomaly - a possible explanation, J. Hydrol., 25, 159-65, 1975.

Gallagher, A. J., Rutter, H. K., Buckley, D. K., and Molyneux, I.: Lithostratigraphic controls on recharge to the Chalk aquifer of Southern England, Q. J. Eng. Geol. Hydroge., 45, 131-142, 2012.

Grindley, J.: The calculation of evaporation and soil moisture deficits over specified catchment areas, Meteorol. Off., Bracknell, Hydrol. Mem., No. 38, 1967.

Habets, F., Gascoin, S., Korkmaz, S., Thiéry, D., Zribi, M., Amraoui, N., Carli, M., Ducharne, A., Leblois, E., Ledoux, E., Martin, E., Noilhan, J., Ottlé, C., and Viennot, P.: Multi-model comparison of a major flood in the groundwater-fed basin of the Somme River (France), Hydrol. Earth Syst. Sci., 14, 99-117, doi:10.5194/hess-14-99-2010, 2010.

Howard, K. W. F. and Lloyd, J. W.: The sensitivity of parameters in the Penman evaporation equations and direct recharge balance, J. Hydrol., 41, 329-344, 1979.

Hughes, A., Vounaki, T., Peach, D., Ireson, A. M., Jackson, C., Butler, A., Finch, J., and Wheater, H. S.: Flood risk from groundwater: examples from in a Chalk catchment in southern England, Journal of Flood Risk Management, 4, 143-155, 2011.

Ireson, A. M. and Butler, A. P.: Controls on preferential recharge to Chalk aquifers, J. Hydrol., 398, 109-123, 2011.

Ireson, A. M., Butler, A. P., and Gallagher, A.: Groundwater flooding in fractured permeable aquifers, in: IAHS Publication 330: Improving integrated surface and groundwater resource management in a vulnerable and changing world, IAHS/AISH, Chichester, 165-172, 2009a.

Ireson, A. M., Mathias, S. A., Wheater, H. S., Butler, A. P., and Finch, J.: A model for flow in the Chalk unsaturated zone incorporating progressive weathering, J. Hydrol., 365, 244-260, 2009b.

Ireson, A. M., Butler, A. P., and Wheater, H. S.: Evidence for the onset and persistence with depth of preferential flow in unsaturated fractured porous media, Hydrol. Res., 43, 707-719, 2012.

Jackson, C. R.: Simple Automatic Time-Stepping for Improved Simulation of Groundwater Hydrographs, Ground water, 50, 736-745, doi:10.1111/j.1745-6584.2011.00898.x, 2011.

Jackson, C. R., Bloomfield, J. P., Buckley, D. K., Chambers, D. E., Darling, W. G., Hughes, A. G., Mansour, M. M., Newell, A. J., Peach, D. W., and Raines, M. G.: Conceptualisation of ground- 
water flow in the Chalk aquifer around Gatehampton, British Geological Survey, Technical report CR/06/206C, 2006.

Jackson, C. R., Meister, R., and Prudhomme, C.: Modelling the effects of climate change and its uncertainty on UK Chalk groundwater resources from an ensemble of global climate model projections, J. Hydrol., 399, 12-28, 2011.

Jackson, D. and Rushton, K.: Assessment of recharge components for a chalk aquifer unit, J. Hydrol., 92, 1-15, 1987.

Jones, M. A., Hughes, A. G., Jackson, C. R., and Van Wonderen, J. J.: Groundwater resource modelling for public water supply management in London, Geological Society, London, Special Publications, 364, 99-111, 2012.

Keating, E. H., Doherty, J., Vrugt, J. A., and Kang, Q.: Optimization and uncertainty assessment of strongly nonlinear groundwater models with high parameter dimensionality, Water Resour. Res., 46, W10517, doi:10.1029/2009WR008584, 2010.

Kessler, H., Mathers, S., and Sobisch, H.: The capture and dissemination fo integrated 3D geospatial knowledge at the British Geological Survey using GSI3D software and methodology, Comput. Geosci., 35, 1311-1321, 2009.

Kosugi, K.: Three-parameter lognormal distribution model for soil water retention, Water Resour. Res., 30, 891-901, 1994.

Kosugi, K.: Lognormal distribution model for unsaturated soil hydraulic properties, Water Resour. Res., 32, 2697-2703, 1996.

Lee, L. J. E., Lawrence, D. S. L., and Price, M.: Analysis of waterlevel response to rainfall and implications for recharge pathways in the Chalk aquifer, SE England, J. Hydrol., 330, 604-620, 2006.

Lee, H., Zehe, E., and Sivapalan, M.: Predictions of rainfall-runoff response and soil moisture dynamics in a microscale catchment using the CREW model, Hydrol. Earth Syst. Sci., 11, 819-849, doi:10.5194/hess-11-819-2007, 2007.

Mander, J. M. and Greenfield, B. J.: Storage and discharge: unconfined aquifers, International Association of Hydrogeologists, Memoirs of Birmingham Congress, UK, 12, D42-D54, 1977.

Mander, J. M. and Greenfield, B. J.: Hydrograph generation and augmented flow analysis, Tech. rep., Thames Groundwater Scheme, Institution of Civil Engineers, London, 1978.

Mathias, S. A., Butler, A. P., McIntyre, N., and Wheater, H. S.: The significance of flow in the matrix of the Chalk unsaturated zone, J. Hydrol., 310, 62-77, 2005.

Mathias, S. A., Butler, A. P., Jackson, B. M., and Wheater, H. S.: Transient simulations of flow and transport in the Chalk unsaturated zone, J. Hydrol., 330, 10-28, 2006.

Morel, E. H.: The use of a numerical model in the management of the Chalk aquifer in the Upper Thames Basin, Q. J. Eng. Geol. Hydroge., 13, 153-165, 1980.

Narasimhan, T. N. and Witherspoon, P. A.: An integrated finite difference method for analyzing fluid flow in porous media, Water Resour. Res., 12, 57-64, 1976.

Palagi, C. and Aziz, K.: Use of Voronoi grid in reservoir simulation, SPE Advanced Technology Series, 2, 69-77, 1994.
Parissopoulos, G. A. and Wheater, H. S.: On numerical errors associated with the iterative alternating direction implicit (Iadi) finite difference solution of the two dimensional transient saturatedunsaturated flow (Richards) equation, Hydrol. Process., 2, 187201, 2006.

Parker, S. J.: Chalk regional groundwater models and their applicability to site scale processes, Ph.D. thesis, Imperial College London, 2011.

Penman, H. L.: The dependence of transpiration on weather and soil conditions, J. Soil Sci., 1, 74-89, 1950.

Peters, R. R. and Klavetter, E. A.: A Continuum Model for Water Movement in an Unsaturated Fractured Rock Mass, Water Resour. Res., 24, 416-430, 1988.

Price, M., Low, R. G., and McCann, C.: Mechanisms of water storage and flow in the unsaturated zone of the Chalk aquifer, J. Hydrol., 233, 54-71, 2000.

Ragab, R., Finch, J., and Harding, R.: Estimation of groundwater recharge to Chalk and sandstone aquifers using simple soil models, J. Hydrol., 190, 19-41, 1997.

Rushton, K. R.: Estimating recharge for British aquifers, Water Environ. J., 19, 115-124, 2005.

Rushton, K. R. and Ward, C.: The estimation of groundwater recharge, J. Hydrol., 41, 345-361, 1979.

Scanlon, B. R., Healy, R. W., and Cook, P. G.: Choosing appropriate techniques for quantifying groundwater recharge, Hydrogeol. J., 10, 18-39, 2002.

Shampine, L. F. and Reichelt, M. W.: The Matlab ODE suite, SIAM J. Sci. Comput., 18, 1-22, 1997.

Smith, D. B., Wearn, P. L., Richards, H. J., and Rowe, P. C.: Water movement in the unsaturated zone of high and low permeability strata using natural tritium, in: Isotope Hydrology, Atomic Energy Agency, Vienna, 1970.

Thompson, N., Barry, I. A., and Ayles, M.: The Meteorological Office rainfall and evaporation calculation system: MORECS, Tech. rep., Meteorological Office, Bracknell, UK, 1981.

Tocci, M. D., Kelley, C. T., and Miller, C. T.: Accurate and economical solution of the pressure-head form of Richards' equation by the method of lines, Adv. Water. Res., 20, 1-14, 1997.

Tóth, J.: A theoretical analysis of groundwater flow in small drainage basins, Geophys. Res., 68, 4795-4812, 1963.

Troch, P. A., Paniconi, C., van Loom, E.: Hillslope-storage Boussinesq model for subsurface flow and variable source areas along complex hillslopes: 1. Formulation and characteristic response, Water Resour. Res., 39, 1316, doi:10.1029/2002WR001728, 2003.

van den Daele, G. F. A., Barker, J. A., Connell, L. D., Atkinson, T. C., Darling, W. G., and Cooper, J. D.: Unsaturated flow and solute transport through the Chalk: Tracer test and dual permeability modelling, J. Hydrol., 342, 157-172, 2007.

Wellings, S. R.: Recharge of the Upper Chalk aquifer at a site in Hampshire, England, 1. Water balance and unsaturated flow, J. Hydrol., 69, 259-273, 1984. 